\title{
Breaking New Frontiers in Nigeria Commercial Agricultural Sector and the Exigency for Active Involvement of Local Governments
}

\author{
Nnadozie, A.K.O (Ph.D) \\ Marketing Department, Federal College of Agriculture, Ishiagu, Ebonyi State, Nigeria \\ Nwangwu, A.O. \\ Marketing Department, Federal College of Agriculture, Ishiagu, Ebonyi State, Nigeria \\ Okereke, S.N \\ Department Of Public Administration, Federal College of Agriculture, Ishiagu, Ebonyi State, Nigeria \\ Egudu, J.I \\ Department of Agricultural Education, Institute of Ecumenical Education, Thinkers Corner, Enugu, Nigeria
}

\begin{abstract}
This paper is an assessment of breaking new frontiers in Nigeria commercial agricultural sector and the exigency for active involvement of local governments. It was concluded that unlocking Nigeria's full agricultural potential requires that Nigeria solve the underlying challenges in its agricultural system, which includes; policy framework, finance and risk management, agricultural technology, political commitment amongst others. The paper recommended that the Local Government Service Commission should be strengthened and accorded constitutional recognition, and given the commission's laudable objectives, such strengthening would support the human resource and staffing development of local governments in Nigeria, furthermore, Local government administrators in Nigeria should be encouraged to implement the agricultural policies of the government at the grassroots.

Keywords: Commercial Agriculture, Third Tier of Government, Grass Root Development, Agricultural Programmes.

DOI: $10.7176 / J E S D / 10-6-09$

Publication date:March $31^{\text {st }} 2019$

\section{Introduction}

Nigeria is facing two key gaps in agriculture today: an inability to meet domestic food requirements and an inability to export at quality levels required for market success. The former problem is a productivity challenge driven by an input system and farming model that is largely inefficient (Friday, O. \& Eddy, O; 2013). As a result, aging populations of farmers do not have enough seeds, fertilizers, irrigation, crop protection and related support to be successful. The latter challenge according to (Nnadozie A.K.O; Ume. S.I., Isiocha S.\& Njoku I.A 2015) is driven by an equally inefficient system for setting and enforcing food quality standards, as well as poor knowledge of target markets. According to Ugwu, Nzeh \& Amakom (2013); insufficient food testing facilities, a weak inspectorate system in FMARD, and poor coordination among relevant federal agencies serve to compound early stage problems such as poor knowledge of permissible contaminant levels.

Putting Nigeria's agriculture sector on a path to growth will require actions to solve these two gaps: produce enough fresh, high quality foods for the Nigerian market; and serve the export market successfully and earn foreign exchange (World Bank 2013). The new federal Agricultural Promotion Policy (APP) is a strategy that focuses on solving the core issues at the heart of limited food production and delivery of quality standards. As productivity improves domestically and standards are raised for all Nigerian food production, export markets will also benefit impacting positively on Nigeria's balance of payments. Given limited resources and the importance of delivering sustainable results, the Federal Ministry of Agriculture \& Rural Development (FMARD) in consultation with partners has identified an initial pool of crops and related activities that will be Nigeria's path to tackling the aforementioned gaps. Thus, at the grass roots, the Nigerian local governments will be at ease to be actively involved in the commercial agricultural sector.

First, FMARD will prioritize improving productivity into a number of domestically focused crops and activities. These are rice, wheat, maize, fish (aquaculture), dairy milk, soya beans, poultry, horticulture (fruits and vegetables), and sugar. Nigeria believes that the gap can be closed by partnering closely with private investors across farmer groups and companies to develop end to end value chain solutions. These chains of given facilitated government support will make deep commitments to engaging a new generation of farmers, improving supply of specialized fertilizers and protection chemicals, as well as wider scale use of high yielding seeds. In addition, Nigeria expects to work with investors to sharply improve the distribution system for fresh foods so as to reduce
\end{abstract}


time to table, reduce post-harvest losses, and overall improve nutritional outcomes e.g. lowering of diabetic risk, stunting risk, etc.

Second, FMARD will prioritize for export markets the production of the following crops and activities: cowpeas, cocoa, cashew, cassava (starch, chips and ethanol), ginger, sesame, oil palm, yams, horticulture (fruits and vegetables), beef and cotton. FMARD will also work with a network of investors, farmers, processors and other stakeholders to deepen the supporting infrastructure to ensure that for quality standards are defined and maintained across the value chain. That will involve adding more testing laboratories, improving traceability of crops, disseminating intelligence on export markets and consumer preferences, etc. Our goal is to build a high quality brand for Nigerian foods based on rigorous data and processes that protect food safety for both domestic and export market consumers with active participation of Local Governments as the third tier and grass root based for effectiveness and increased small holder farmers' productivity across the Nigerian states.

To ensure that the strategy is executed as intended, FMARD should closely work with local governments, states and other federal MDAs e.g. Power, Transportation and Trade. FMARD will also evolve itself to become a more focused policy maker and regulator to ensure accountability for results. FMARD will use its convening and related powers to ensure that the enabling system is in place to support agribusiness. From investments in rural roads to reduce transport time to improved security of farming communities to reduce incidence of criminality to reduction in intra-state taxes and levies, FMARD will intensify oversight at the third tier of government |the local government.

That oversight will ensure that farmers and investors are working in a market that is safe, competitive, and capable of enabling wealth creation in the coming years and decades. Hence, the need for active participation of local governments in commercial agricultural sector of Nigerian economy.

\section{Problem Statement}

Nigeria is facing two key gaps in agriculture today: an inability to meet domestic food requirements and an inability to export at quality levels required for market success (World Bank, 2013).

\section{Brief History of Nigeria Local Government Councils}

Nigeria Local government councils did not have definitive constitutional recognition until local government was enshrined in the 1979 constitution, which provided the legal framework to implement the 1976 reforms. The primary goal was to ensure that every state government should, by law, provide for the establishment, structure, composition, finance and functions of local councils (Diejomoah and Ebo 2010). However, this means that the degree of autonomy local councils enjoy in decision-making, strength and relevance is determined by their respective state governments, and state governments have always taken advantage of the lacuna created by this constitutional framework to dictate the financial and operational structures of local governments. The 1979 constitution did spell out the functions and responsibilities of local government. The Functions fall into three categories: areas for which local governments have full responsibility, areas where local government shares responsibility with higher levels of government, and areas of responsibility that the state or federal government may from time to time assign to local authorities (Oviasuyi et al. 2010). Local government is seen as that part of the government of a nation or state which deals mainly with such matters as concerns the inhabitants of a particular district or place Clarke (1948) cited in Sharma et al (2012). It is that part of government which deals with local or grassroots affairs, administered by elected or appointed authorities, subordinate to the state. Okoli (2005) conceived local government as a unit of government established by act of law to administer the functions of government and see to the welfare and interest of the local dwellers under the local government system. The Guidelines for Local Government Reform of (1976:1) defines local government as:

"Government at the local level exercised through representative council established by law to exercise specific powers within a defined area. These powers should give the council substantial control over local affairs as well as the staff and institutional and financial powers to initiate and direct the provision of services and to determine and implement projects so as to complement the activities of state and federal government in their areas and to ensure through devolution of functions to these councils and through the active participation of the people and their traditional institutions, that local initiative and response to local needs and conditions are maximized."

The following characteristics of local government are evident:

i) A local government is a subdivision of a country that is closest to the citizens and is generally referred to as the third tier of government in a federal state such as Nigeria.

ii) A local government exists within a clearly defined territory recognized by inhabitants and neighboring local governments.

iii) It is empowered to control local affairs and can raise revenue through taxes and other approved means and incur expenses.

iv) It is a legal entity which can sue and be sued. 


\section{Reasons for the Establishment of Local Government in Nigeria}

According to Aguwa (2006) and Okereke et al (2016), the following reasons were advanced for the creation of local governments in Nigeria: Bringing government nearer to the people; Local government acts as a vehicle for the articulation and promotion of local interests; It serves as a veritable launch-pad for political education; Engenders stability of the national political system; It helps mobilize and harness local resources; It is an instrument employed in the decentralization process by state government; Engenders communication; It is an agent of rural development; It guarantees local autonomy; It preserves the people's cultures.

In addition to the above, The 1999 Constitution of Nigeria as contained in the Fourth Schedule, Section 7 outlined the following as the roles of the Local government councils towards agricultural development transformation: establishment, maintenance and rural infrastructures such as feeder roads, health centers, regulation of slaughter houses, slab, markets, gardens, water and electricity, build more primary and secondary parks; participation in the development of agriculture and natural resources, other than the exploitation of minerals.

Furthermore, according to Mgbenka et al (2015) based on the New Nigeria Agricultural Policy, the Local government councils were created with the expectation for them to take over progressively the provision of an effective extension services; provision of rural infrastructure to complement federal and state governments' efforts; management of irrigation areas of dams; mobilization of farmers for accelerated agricultural and rural development through cooperative organizations, local institutions and communities; provision of land for new entrants into farming in accordance with the provision of the Land Use Act; and coordination of data collection at primary level. It was envisaged that local government could help to provide rural infrastructures such as feeder roads, health centers, water and electricity, build more primary and secondary schools, provide agro-services to mention but a few. It is also the responsibility of Local government councils (LGCs) to ensure that land preparations equipment such as heavy duty equipment to open the land and tractors are available for farmers to use at appropriate time and at a subsidized rate.

The LGCs are therefore responsible for agricultural and rural development in their areas of jurisdiction as stipulated in the 1999 Constitution. It is therefore evident that local government councils occupy a strategic position in the food production chain both at the small scale or commercial level in Nigeria. This, according to Anikpo (2008) can be achieved through support for agro-allied industries and farming extension services, as well as in the grassroots mobilization of the rural populace for the desired transformation of the rural areas.

\section{Functions of Local Government}

The functional areas for local government included in the Nigerian constitution are:

i. $\quad$ Provision and maintenance of health services;

ii. Agricultural and national resource development;

iii. Provision and maintenance of primary, adult and vocational education; and

iv. Other functions as may be conferred on it by the state house of assembly.

v. Section 7(1) also guarantees democratically elected governments in Nigeria.

vi. Collection of rates and licenses on radio and television.

vii. Licensing of bicycles, trucks, canoes, wheel barrows, carts, etc.

viii. Establishment, maintenance and regulation of markets, motor parks, etc.

ix. Registration of births, deaths and marriages in their areas of authority.

x. Assessment of privately owned houses or tenements for the purpose of levying such rates.

xi. Naming of roads, streets, etc.

Zero Hunger Campaign Nigeria and the Need for Local Government Participation:

The Federal Republic of Nigeria is committed to achieving the 2030 Agenda for Sustainable Development as well as measuring and monitoring progress towards the goals and targets that Heads of State and Government collectively agreed at the Special Summit of the United Nations held in September 2015. The principal targets of SDG 2 are ending hunger and ensuring access to safe, nutritious, and sufficient food; ending all forms of malnutrition; doubling the productivity and incomes of small-scale food producers; ensuring sustainable food production systems and implementing resilient agricultural practices; and maintaining the genetic diversity of seeds, plants, and animals. Supplemental measures to promote the achievement of the targets include increasing investment, correcting and preventing trade restrictions and distortions, and ensuring the proper functioning of food commodity markets.

The Nigeria Zero Hunger Strategic Review sought to articulate what Nigeria must do to achieve SDG 2 (zero hunger) by 2030 through an open and consultative process aided by the local government councils. Chief Olusegun Obasanjo, former President of the Federal Republic of Nigeria, convened and chaired the multi stakeholder review work, which was organized around nine subcommittees. Through research and consultation, the subcommittees established subject-specific baselines that fostered joint understanding of the challenges and gaps in the national response to food and nutrition insecurity; contributed to consensus on priority actions required to achieve zero 
hunger in Nigeria by 2030; and led to the development of a road map for tracking progress on the implementation of the review and they are;

1. End hunger and ensure access by all people (SDG 2.1) - Nigeria has made good progress over the past 25 years, reducing by nearly half the proportion of people suffering from hunger. However, this progress has been slowed or even reversed during the past decade. Nearly 13 million Nigerians still suffer from hunger, with wide disparities across geopolitical zones and between urban and rural areas. These unfavorable trends are due in part to limited gains in food security and nutrition relative to rapid population growth.

2. End all forms of malnutrition (SDG 2.2) - Gains against under nutrition since 1991 have stalled, especially in the prevention of stunting among children. One-third of children aged 5 years and under (over 10 million) suffers from stunting, another $25 \%$ are underweight, and $15 \%$ of infants have low birth weight. In the Northern states, stunting affects nearly $55 \%$ of children, and child malnutrition is four times higher than in the South. Poor maternal nutrition and practices for feeding infants and young children, lack of access to nutritious food, and inadequate health services are the underlying causes of child malnutrition. Priorities in these frameworks include major scaling-up for stunting prevention, and the targeting of pregnant and lactating women and children through the 1000 day window of opportunity from conception to when the child is 2 years. However, the range of nutrition-specific and nutritionsensitive interventions implemented in Nigeria is not on a scale that is necessary and appropriate, relative to the magnitude of the problem. More efforts are needed to promote, protect, and support breastfeeding at the grass roots using local government councils. Nigeria has the highest population of stunted children under 5 in sub Saharan Africa, and the second highest in the world (after India); 37\% are stunted and 19\% severely stunted. This, therefore, need an active involvement of local governments.

3. Double the agricultural productivity and incomes of small-scale food producers (SDG 2.3) - Over the past quarter decade, agricultural production has varied widely. Food production stagnated before 1986, increased steadily to 2006, and then declined. Agricultural production improved greatly during the 1986 structural adjustment period, in part as a response to a surge of Government investment in agriculture and infrastructure that peaked by 2002. Production growth continued to improve in subsequent years, but at a slower rate compared with the average annual rate of growth of the population. Growth across subsectors remains erratic. Smallholder agricultural producers \rural or local farmers constitute the vast majority of rural dwellers, farming on one to five hectares of land, on average, that too often fail to produce surpluses, and being so deeply trapped in poverty that they alone do not possess the capacity to eliminate the triad of hunger, food insecurity, and malnutrition. Their food value chains are largely undeveloped. Nigeria's fast-growing population and high rate of urbanization have created a food deficit of 56 million tonnes that presents opportunities for market-oriented smallholders. The total population of approximately 182 million people (NESG 2015), with 48\% living in urban settlements, is expected to double by 2040. Urban demand for food is expanding in terms of expected quality and range of products; this also offers excellent opportunities not only for increasing food production but also for adding value to agricultural produce and thus earning more income. Closing the food deficit will require the modernization of smallholder agriculture production, including through increased public and private sector investments in irrigation and farmer training to improve yields and expand production areas; more sustainable management of agricultural resources that include the land; and better use of genetic plant and animal resources. Hence, the pivotal need for local and state governments to be actively engaged to engender job and wealth creation.

4. Ensure sustainable food production systems and implement resilient agricultural practices (SDG2.4) - The increased occurrence of natural and man-made disasters across Nigeria, exacerbated by the poor coping and adaptation strategies of farmers and vulnerable populations, exposes rural producers to hazards in terms of the destruction of farmland, premature harvesting, and displacement. Available evidence shows that in the last decade, short-duration climatic oscillations have made it difficult for rural producers to plan crop calendars, which affects farmers' productivity. Modernization of agriculture and more sustainable management of agricultural resources are the key to achieving zero hunger. Improved targeting of production inputs, including seeds, mineral and organic fertilizers, soil conditioners, pesticides and herbicides, is needed across all commodities; and Integrated Soil Fertility Management (ISFM) and Integrated Pest Management (IPM), two production approaches in which Nigerian institutions have strong capacities, will be necessary. Facilities for irrigated rice, maize, banana, ginger, green vegetables, and tomato require expanded irrigation systems and efficient use of available dams to reach production targets; and both horticultural and nursery production systems also require a reliable, high quality water supply. Coordinated efforts by the Federal Ministry of Water Resources, River Basin Development Authorities, different local | State governments irrigation projects, and the irrigation schemes of the private sector are critical. 
5. Maintain the genetic diversity of seeds, cultivated plants, and farmed and domesticated animals and their related wild species (SDG 2.5) - Improved quality and availability of crop seeds and expansion of vegetative and nursery propagation systems are important aspects of sustainable agriculture, also the broadening of dietary diversity among both rural and urban populations. Improved varieties for rice, maize, and soybean have been developed but incentives are needed to reinforce seed systems through commercial channels. Seed-planted crops (hybrid tomato, green vegetables, sesame, and tree crops) require research and genetic improvement before being commercialized as breeder, foundation, and certified seeds.

The local government councils in Nigeria have sought full involvement in the above stated approaches, in order to promote commercial agriculture.

\section{Conclusions}

Unlocking Nigeria's full agricultural potential requires that Nigeria solve the underlying challenges in its agricultural system, which includes the following:

- Policy Framework: Nigeria suffers from policy instability driven by high rate of turnover of programmes and personnel, which in turn has made the application of policy instruments unstable. To address this challenge, Nigeria needs to create a policy structure that matches evidence-driven coordination among decision-making authorities with common and public goals for an agricultural transformation of the country. Building that evidence base requires that Nigeria adopt a consistent fact base to drive decision making, as well as build on prior successes e.g. the Jonathan Administration's pioneering Agricultural Transformation Agenda (ATA).

- Political Commitment: This pertains to the non-implementation of international protocols or conventions agreed to with other members of the comity of nations. For example, Nigeria has failed to achieve the targets in the Maputo Declaration that prescribes a minimum of $10 \%$ budgetary allocation to the agricultural sector. Political commitment at both the Federal and State levels will be required to enforce reforms.

- Agricultural Technology: Persistent shortcomings of the National Agricultural Research System (NARS) to generate and commercialize new agricultural technologies that meet local market needs. NARS's challenges have been relatively severe particularly around improved varieties of seed or other planting materials and breeds of livestock and aquatic species. Addressing these will require better coordination among extension delivery system, the national agricultural research system, as well as public and private sector suppliers of agricultural inputs.

- Infrastructure Deficit: Nigeria's agricultural sector suffers from an infrastructure challenge. Infrastructure such as motor roads, railroads or irrigation dams are either insufficient, or when available, not cost competitive. They are thus unable to operate to support scale-driven agriculture. Nigeria will need to rethink the business and operating model for agricultural infrastructure

- Finance and Risk Management: Nigeria's agriculture sector continues to have poor access to financial services that enable farmers and other agricultural producers to adopt new technologies, improve market linkages, and increase their resilience to economic shocks. To improve financing options and de-risk value chains further, Nigeria will need to intensify innovation in financing ecosystems.

- Institutional Reform and Realignment: Today, many federal and state agricultural institutions only exist on paper. In fact, the system even ignores local government areas which are actually where a majority of activity takes place. There is a need to streamline, clarify mandates and ensure continued accountability for results.

In addressing these constraints, the three tiers of governments will apply prudent, market based policy measures to grow the sector, with a clear recognition that widespread poverty reduction through the transformation of the agriculture sector is integral to the country's long run economic growth trajectory and prosperity.

\section{Recommendations}

The Local Government Service Commission should be strengthened and accorded constitutional recognition. Given the commission's laudable objectives, such strengthening would support the human resource and staffing development of local governments in Nigeria. Furthermore, Local government administrators in Nigeria should be encouraged to implement the agricultural policies of the government at the grassroots. This can be achieved by by-passing the state government in the distribution of agricultural inputs to local farmers. In addition to the raising the human capital value of local government employees through employment of competent staff and the training and retraining of extension workers at the local government councils, local government administrators should be encouraged to venture into active agriculture.

Finally, the minimum qualifications for eligibility to seek election as a local government chairperson should be reviewed. In the light of the complex tasks of local governance and inclusive participation, the authors 
recommend that in order to stand as a local councilor, candidates should have a National Diploma or above, and at least 15 years of relevant experience. This recommendation is seen as fundamental to developing local leadership skills, which will enable local politicians to achieve national relevance.

\section{References}

Aguwa, A. N. (2006). Local Government Administration. Aba: Cheedal Global Prints Limited. pp. 44-48.

Anikpo, M. (2008).The Local government and rural transformation in Nigeria: Problems, prospects, roles and responsibilities. Paper presented at seminar on the new focus on rural development towards 2020 held at FCT, Abuja, 13 - 15 May.

Constitution of the Federal Republic of Nigeria (1979) Available at: http://www.constitutionnet.org/vl/item/constitution-federal-republic-nigeria-1979 [Accessed 5 January 2018].

Constitution of the Federal Republic of Nigeria (1999) Available at: http://www.nigerialaw.org/ConstitutionOfTheFederalRepublicOfNigeria.htm [Accessed 1st February 2018].

Diejomaoh, I. and Eboh, E. (2010) Local governments in Nigeria: Relevance and effectiveness in poverty reduction and economic development. Journal of Economics and Sustainable Development, 1 (1), 12-28.

Federal Republic of Nigeria (1976), Guideline for Local Government Reform. Kaduna: Government Printer.

Friday, O. \& Eddy, O. (2013). Empirical Analysis of Factors Affecting Productivity Among Fadama Farmers in Edo state, Nigeria. International Journal of Advancements Research \& Technology. Vol,2(2) 201-211.

Mgbenka R.N, Mbah E.N and. Ezeano C.I (2015) The Role of Local Government Council in Agricultural Transformation in Nigeria: Need for Review of Policy Agricultural Engineering Research Journal 5(2): 27 32.

Nnadozie A.K.O; Ume S.I., Isiocha S. \& Njoku I.A (2015). Extension Farmer- Input Linkage System (REFILS) by Agricultural Development Programmes (ADPs) in Nigeria, 1986-2011, Science Journal of Business Management: Special Issue: Sustainable Entrepreneurial Developments in Agribusiness. Vol.3no5-1pp41-46.

Okoli, M.U. (2005). Local Government Administrative System: An Introductory and Comparative Approach. Onitsha: Abbot Books Limited.

Ositanwosu C.and Qiquan X. (2016).Journal of Economics and Sustainable Development www.iiste.org ISSN 2222-1700 (Paper) ISSN 2222-2855 (Online) Vol.7, No.8.

Oviasuyi, P.O., Idada, W. and Isiraojie, L. (2010) Constraints of local government administration in Nigeria.Journal of Social Science, 24 (2), 81-86.

Sharma, M.P. et al (2012). Public Administration in Theory and Practice.Allahabad: Kitab Mahal Printing division. Ugwu D.S, Nzeh E. C. P, \& Amakom. U. (2013). Agriculture as a Potent Economic Growth Driver for Nigeria Economy. Afri-Heritage Research Working Paper-03.

World Bank (2013). Agriculture and its Contributions to Nigeria’s Growth. Washington D C. 